\title{
Floristic composition of weeds in different winter and summer covers
}

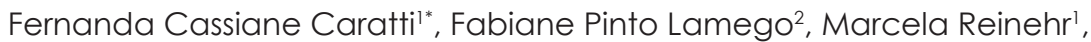 \\ Mirian Fracasso Fabiani', Daiane Frizon', Marines Mazzon'
}

\begin{abstract}
The usage of cover crops is an adopted cultural measure that shows positive effects when associated with the no-till system and weed management. During the cycle of the plants there might be competition within them for water, solar radiation and nutrients and effects of allelopathic substances released by leaching, volatilization and/or root exudation in the environment might also coexist. The study aimed to quantify the floristic composition of weed species in an cultivated area with cover crops during winter and summer, for two years, 201 1/12 and 2012/13, in an experimental area of UFSM, Campus of Frederico Westphalen - RS state, Brazil. The treatments consisted of Italian ryegrass, wild radish, black oat, vetch, wheat and uncultivated, in winter, and, sorghum, sunflower, black velvet bean, dwarf velvet bean, gray velvet bean and green velvet bean in the summer. In the first year of the experiment, a diversity of weeds in winter was observed, especially occuring Stellaria media and Bowlesia incana. In summer, the weeds of higher importance were Ipomoea spp. and Bidens spp., both of utter importance in agricultural systems. Winter cover crops of wild radish and Italian ryegrass and summer cover crops of sorghum and sunflower provided a lower weed infestation
\end{abstract}

Keywords: phytosociological survey, straw; suppression, Italian ryegrass

\section{Introduction}

Among the cultural tools to manage weed species, the usage of soil covering plants in a no-till system is a practice that shows positive effects, since the straw of the previous crop aids in the emergency suppression of weeds, through physical and allelopathic effect (Constantin, 2007). Physically, the cover plant has influence over light, temperature and soil moisture, hardening the dormancy breaking process and preventing the germination of seeds and/or propagules of weeds, acting as a mechanical barrier. As to the chemical effects, they might occur through the release of known substances in the environment, known as allelochemicals
(Souza et al., 2006), which might compromise the germination and the development of weeds (Pires \& Oliveira 2007).

It is desirable that the cover plants provide nutrients for cultivated plants through straw decomposition, but also that they suppress the weeds. (Moraes et al., 2009). The allelopathic action, during the vegetative growth and in the decomposition process of vegetal remainings, exercises interspecific inhibition over other species (Meschede et al., 2007). This occurs due to the reduced availability of light and to the consequences of the acting compounds (Kadioglu et al., 2005).

Among the benefits that soil coverings 
proportionate to the crops, the effect of emergence suppression of weeds is highlighted, associated to a possible reduction in the application of herbicides. This practice might complement the chemical method of weed control, since the residues of the previous crop reduces or delays the emergence of unwanted plants (Rizzardi \& Silva, 2006).

The evaluation of weed species occurring under field conditions of different covering plants might be performed through a phytosociological survey. Phytosociology is comprehended as one of the most utilized methods in the floristic reconnaissance of agricultural areas, being proposed by Mueller \& Ellemberg (1974). It is possible to stablish, for example, the occurrence frequency of a determined species in an area. Associating this information with the usage of different soil covering plants both in winter and in summer, it is possible to estimate which covering has a greater or lesser suppressing effect over infesting weeds.

This work aimed to identify and to quantify the floristic composition of weeds through phytosociological characterization in a cultivated area with covering plant species during two growing seasons, winter and summer, with the objective of verifying the suppression capacity of covering species over the weeds.

\section{Material and Methods}

The work was carried out in the agricultural years of 2011/2012 and 2012/2013 in an experimental area of the Federal University of Santa Maria - UFSM, Campus of Frederico Westphalen, Rio Grande do Sul state, Brazil, under the coordinates $27^{\circ} 21^{\prime} 33^{\prime \prime}$ S, 53⒉ $43^{\prime \prime}$ $W$ and at $522 \mathrm{~m}$ of altitude. The adopted experimental design was in randomized blocks, with four repetitions, with the experimental units of $4 \mathrm{~m}^{2}(2,0 \mathrm{~m} \times 2,0 \mathrm{~m})$. The treatments utilized as covering plants are listed on Table 1. Previously to the sowing of the winter and summer coverings,

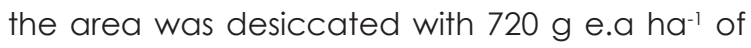
the glyphosate herbicide.

Table 1. Species of ground couver applied in succession during the periods of summer and winter. UFSM, Campus de Frederico Westphalen, RS, 2011/12 - 2012/13.

\begin{tabular}{|c|c|c|c|c|}
\hline Treatment & Commom name & Scientific name & Family & $\begin{array}{l}\text { Density } \\
\text { pl ha }^{-1}\end{array}$ \\
\hline \multicolumn{5}{|c|}{ Winter cover } \\
\hline $\mathrm{T} 1$ & Fallow & - & - & - \\
\hline T2 & Italian ryegrass & Lolium multiflorum & Poaceae & 300.000 \\
\hline T3 & Turnip & Raphanus spp & Brassicaceae & 30.000 \\
\hline $\mathrm{T} 4$ & Vetch & Vicia sativa & Leguminosae & 150.000 \\
\hline T5 & Black oats & Avena strigose & Poaceae & 300.000 \\
\hline T6 & Wheat (cv. Quartzo) & Triticum aestivum & Poaceae & 300.000 \\
\hline \multicolumn{5}{|c|}{ Summer cover } \\
\hline $\mathrm{Tl}$ & Black velvet bean & Mucuna aterrima & Fabaceae & 30.000 \\
\hline $\mathrm{T} 2$ & Gray velvet bean & Mucuna cinerea & Fabaceae & 30.000 \\
\hline T3 & Sorghum & Sorghum bicolor & Poaceae & 150.000 \\
\hline $\mathrm{T} 4$ & Sunflower & Helianthus annuus & Asteraceae & 40.000 \\
\hline T5 & Dwarf velvet bean & Stizolobium deeringianum & Fabaceae & 30.000 \\
\hline T6 & Green velvet bean & Mucuna pruriens var.utilis & Fabaceae & 30.000 \\
\hline
\end{tabular}

The sowing of the covering species for the winter was performed through broadcast sowing, on June 5, 2011, and June 9, 2012, in density, aiming to stablish the plant population in the area, according to the technical recommendation for each covering (Table 1). In the first year of the experiment implantation an infestation of the parcels was performed with seeds of Bidens spp., in the population of 21 plants $\mathrm{m}^{-2}$, at the same moment of the covering sowing. The sowing of the summer covering plants was performed on November 10, 2011, and November 19, 2012, according to the described for the winter coverings (Table 1). Fertilization with NPK (05-20- 
30) was performed in the dosage of $300 \mathrm{Kg} \mathrm{ha}^{-1}$, in both years and for both sowing seasons.

The evaluation of the weed species in winter was performed through phytosociological survey at 90 days after sowing (DAS) of the winter coverings, which were near to the end of the cycle. For the summer coverings, the evaluation of weed species was performed at 28 days after seedling emergence (DAE) of the coverings, when they were already stablished in the area and inside the critical period of interference prevention. Such proceedings were identical in the two years in which the research was conducted.

The sampling for the survey was performed by randomly casting a hollow quadrant with an internal area of $0,25 \mathrm{~m}^{2}$, one time per parcel, according the methodology proposed by Oliveira \& Freitas (2008). The plants were counted and identified according to Lorenzi (2006). The shoot dry matter (SDM) of the vegetal coverings in winter and summer was obtained through collection of the pre-flowering shoot parts and desiccation in Kiln at $60^{\circ} \mathrm{C}$, until reaching constant weight.

With the collected information, the following phytosociological parameters were calculated: frequency loccurrence rate of species in each square), density (amount rate of individuals of a same species in each square), abundance (concentration of the species in different points of the total area), relative frequency, relative density and relative abundance (relating one species to all remaining species in the area) and the importance value index, according to Mueller \& Ellenberg (1974), based on the following equations:

$$
\begin{gathered}
\text { Frequency }=\frac{\text { Number of releases that contain the species }}{\text { Total number of releases }} \\
\text { Relative Frequency }=\frac{\text { Species frequency } \times 100}{\text { Total frequency of all species }} \\
\text { Density }=\frac{\text { Total number of individuals per species }}{\text { Total area sampled }} \\
\text { Relative density }=\frac{\text { Species density } \times 100}{\text { Total density of all species }} \\
\text { Abundance }=\frac{\text { Total number of individuals per species }}{\text { Number of releases that contain the species }} \\
\text { Relative abundance }=\frac{\text { Species abundance } \times 100}{\text { Total abundance of all species }}
\end{gathered}
$$

Importance Value Index=Relative frequency +Relative density+ Relative abundance

\section{Results and Discussion}

In the winter period, the production of shoot dry matter (SDM) for the wheat treatment was superior to the remaining soil covering species for both years, with an average of $6548,80 \mathrm{~kg} \mathrm{ha}^{-1}$ in 2011 and $6625,12 \mathrm{~kg} \mathrm{ha}^{-1}$ in 2012 (Table 2). The second higher production of SDM was obtained by the wild radish $\left(5611,20 \mathrm{~kg} \mathrm{ha}^{-1}\right)$ in 2011; as to the 2012 period the second higher production of SDM was recorded with wild radish 15193,70 $\mathrm{kg} \mathrm{ha}^{-1}$ ) and also with black oat (4914,00 kg ha '). Among covering species, vetch presented a lower amount of SDM when sampling both years of experiment conduction, with averages equivalent to 956,80 and $1023,09 \mathrm{~kg} \mathrm{ha}^{-1}$ for 2011 and 2012 respectively (Table 2 ).

In the summer period the higher production of SDM was recorded for sunflower, compared to the remaining covering species in both years, with an average production equivalent to 17465,20 and $15836,27 \mathrm{~kg} \mathrm{ha}^{-1}$ for both periods of 2011/2012 and 2012/2013, respectively (Table 2 ). The second higher SDM production was obtained by sorghum for both crops, followed by the black velvet bean and the dwarf velvet bean, with the lowest SDM production observed for the gray velvet bean (2844,80 kg ha-1) in 2011/2012 and for gray velvet bean $\left(2853,34 \mathrm{~kg} \mathrm{ha}^{-1}\right)$ and green velvet bean $\left(2975,30 \mathrm{~kg} \mathrm{ha}^{-1}\right)$ in 2012/2013 (Table 2). High 
amounts of dry mass over the soil tend to reduce the establishment of weed species in function of the thermal amplitude reduction by the formation of a physical barrier (Monquero et al., 2009; Gomes Jr. \& Christoffoleti, 2008), hardening the emergence of weeds. Thus, the higher the SDM production obtained by the coverings, the higher the suppression capacity on weed species.

According to the performed phytosociological surveys, the presence of a large seed bank of weeds in the experimental area was discovered, a fact observed both in winter and in summer. For the winter essays, a higher incidence of weed species was recorded in the uncultivated treatment. Regarding the families of the present species, a higher diversity was also observed for this treatment (uncultivated) in both evaluated years.

In 2011, the lowest numbers of weed species were recorded in the treatments with wild radish and ryegrass coverings, with ten species observed for each treatment. In the following year, the lowest infestation diversity was again observed for the wild radish and ryegrass coverings, with seven and eight identified species, respectively (Table 3 ).

Table 2. SDM $\left(\mathrm{kg} \mathrm{ha}^{-1}\right)$ from the covering plants used on both winter and summer. UFSM, Frederico Westphalen Campus -RS, 2011 and 2012/13.

\begin{tabular}{|c|c|c|c|c|c|}
\hline \multirow{2}{*}{ Covering } & \multicolumn{2}{|c|}{ MSPA - Winter } & \multirow{2}{*}{ Cover } & \multicolumn{2}{|c|}{ MSPA - Summer } \\
\hline & 2011 & 2012 & & $2011 / 2012$ & $2012 / 2013$ \\
\hline Fallow & $2140.80 e^{*}$ & $1876.40 \mathrm{~d}$ & Sunflower & $17465.20 \mathrm{a}$ & $15836.27 \mathrm{a}$ \\
\hline Black oats & $4864.00 \mathrm{C}$ & $4914.00 \mathrm{~b}$ & Sorghum & $12167.60 \mathrm{~b}$ & $11978.56 \mathrm{~b}$ \\
\hline Turnip & $5611.20 \mathrm{~b}$ & $5193.70 \mathrm{~b}$ & Black velvet bean & $3563.20 \mathrm{c}$ & $3457.28 \mathrm{c}$ \\
\hline Vetch & $956.80 \mathrm{f}$ & $1023.09 \mathrm{e}$ & Gray velvet bean & 2844.80 e & $2853.34 \mathrm{~d}$ \\
\hline Wheat & $6548.80 a$ & $6625.12 \mathrm{a}$ & Dwarf velvet bean & $3460.80 \mathrm{c}$ & $3376.89 \mathrm{c}$ \\
\hline Italian ryegrass & $4315.20 \mathrm{~d}$ & $4335.30 \mathrm{c}$ & Green velvet bean & $3206.40 \mathrm{~d}$ & $2975.30 \mathrm{~d}$ \\
\hline C.V.' (\%) & 3.5 & 5.2 & & 0.8 & 2.4 \\
\hline
\end{tabular}

Table 3. Total number of weed species and its families (plants $\mathrm{m}^{-2}$ ), identified through a phytosociological survey at 90 days after seeding (DAS) of the covering plants during the winter. UFSM, Campus de Frederico Westphalen, RS, 2011-2012.

\begin{tabular}{|c|c|c|c|c|}
\hline \multirow[t]{3}{*}{ Treatment } & \multicolumn{4}{|c|}{90 DAS } \\
\hline & \multicolumn{2}{|c|}{ total Number of species } & \multicolumn{2}{|c|}{ Families } \\
\hline & 2011 & 2012 & 2011 & 2012 \\
\hline Fallow & $19 a$ & $17 a$ & $9 a$ & $10 a$ \\
\hline Ryegrass & $10 \mathrm{~b}$ & $8 c$ & $5 b$ & $4 \mathrm{~b}$ \\
\hline Turnip & $10 \mathrm{~b}$ & $7 \mathrm{c}$ & $5 \mathrm{~b}$ & $5 \mathrm{~b}$ \\
\hline Black oats & $15 a$ & $13 a b$ & $9 a$ & $6 b$ \\
\hline Wheat & $15 a$ & $10 \mathrm{bc}$ & $7 a b$ & $4 \mathrm{~b}$ \\
\hline Vetch & $15 a$ & $16 a$ & $5 \mathrm{~b}$ & $7 \mathrm{ab}$ \\
\hline c.v. (\%) & 15,2 & 17,4 & 25,9 & 25,9 \\
\hline
\end{tabular}

The usage of wild radish and ryegrass as soil covering plants during winter presented superior results when compared to the remaining evaluated species as to weed suppression in both evaluation years (Table 3 ). The remaining covering plants, wheat, black oat and vetch did not differ from the uncultivated treatment in 2011; as to the second year, the covering composed by black oat and wheat straw ranked in an average situation compared to the total number of species, which were able to reduce the number of weed species in the area, compared to the uncultivated treatment.

Concerning the number of families obtained in the 2011 survey, the coverings with ryegrass, wild radish, wheat and vetch were inferior to the result obtained in the uncultivated condition, which was similar to the black oat and also did not differ from wheat (Table 3). In the following year all utilized covering species reduced the number of families obtained with the evaluations, when compared to the result 
found for the uncultivated condition, except for the vetch, which did not differ within conditions (Table 3). It allowed to infer, on a general manner, that the usage of soil coverings in the winter period tend to lower the number of weed species throughout the years, turning out to be an important tool in the integrated management for the control of weeds. The usage of covering plants in no-till systems contributes for the reduction of weeds in the crops. However, the intervention with herbicides is usually important to avoid yield reduction in function of weed interference (Balbinot Jr et al., 2007), highlighting the importance of the integrated management.

As to the importance value index (IVI) calculated at 90 DAS, it is observed that in 2011 the weed species Bowlesia incana, belonging the Apiaceae family, presented the highest value for the treatments with ryegrass $(75,01)$, wild radish $(65,36)$ and wheat $(44,43)$. As to the treatments composed by black oat and vetch, the species which presented highest IVI was Stellaria media, weed plant belonging to the Caryophyllaceae family, with values equivalent to 45,53 and 38,11 , respectively. For the uncultivated treatment, the species with highest IVI was Ipomoea spp. $(33,67)$, weed plant of the Convolvulaceae family. Unwanted plants belonging to the Commelinaceae, Asteraceae and Plantaginaceae families did also present considerable IVI (Table 4).

Table 4. Species, frequency (F), dominance (D), abundance (A), relative frequency (RF), relative dominance (RD), relative abundance (RA) and importance value index (IVI) of all identified weed species on the phytosociological survey 90 DAS (Days After Seeding), in winter covering plants. UFSM, Campus de Frederico Westphalen, RS, 2011.

\begin{tabular}{ccccccccc}
\hline Treatment & Specie & $\mathrm{F}$ & $\mathrm{D}$ & $\mathrm{A}$ & $\mathrm{FR}(\%)$ & $\mathrm{DR}(\%)$ & $\mathrm{AR}(\%)$ & $\mathrm{IVI}$ \\
\hline \multirow{4}{*}{ Fallow } & Bowlesia incana & 0,50 & 28,00 & 14,00 & 5,71 & 8,97 & 8,50 & 23,18 \\
& Ipomoea spp. & 0,75 & 48,00 & 16,00 & 8,57 & 15,38 & 9,72 & 33,67 \\
& Stellaria media & 0,50 & 36,00 & 18,00 & 5,71 & 11,53 & 10,93 & 28,17 \\
\cline { 2 - 8 } Ryegrass & Bowlesia incana & 0,75 & 72,00 & 24,00 & 13,64 & 34,61 & 26,76 & 75,01 \\
& Apium leptophyllum & 1,00 & 36,00 & 9,00 & 18,18 & 17,31 & 9,21 & 44,70 \\
& Sonchus oleraceus & 0,75 & 20,00 & 6,67 & 13,64 & 9,62 & 6,83 & 30,08 \\
\cline { 2 - 8 } Turnip & Bowlesia incana & 1,00 & 40,00 & 10,00 & 25,00 & 29,41 & 10,95 & 65,36 \\
& Murdannia nudiflora & 0,25 & 20,00 & 20,00 & 6,25 & 14,71 & 21,90 & 42,85 \\
& Soliva pterosperma & 0,25 & 20,00 & 20,00 & 6,25 & 14,71 & 21,90 & 42,85 \\
\cline { 2 - 8 } Vetch & Stellaria media & 0,75 & 36,00 & 12,00 & 12,50 & 15,38 & 10,23 & 38,11 \\
& Murdannia nudiflora & 0,50 & 28,00 & 14,00 & 8,33 & 11,97 & 11,93 & 32,23 \\
& Apium leptophyllum & 0,75 & 34,00 & 11,33 & 12,50 & 14,53 & 9,66 & 36,69 \\
\cline { 2 - 8 } Black oats & Bowlesia incana & 1,00 & 40,00 & 10,00 & 14,81 & 18,87 & 9,32 & 43,00 \\
& Stellaria media & 0,75 & 44,00 & 14,67 & 11,11 & 20,75 & 13,67 & 45,53 \\
& Plantago tomentosa & 0,75 & 20,00 & 6,67 & 11,11 & 9,43 & 6,21 & 26,76 \\
\cline { 2 - 8 } Wheat & Bowlesia incana & 0,75 & 52,00 & 17,33 & 10,00 & 19,05 & 15,38 & 44,43 \\
& Stellaria media & 0,75 & 40,00 & 13,33 & 10,00 & 14,65 & 11,83 & 36,49 \\
& Murdannia nudiflora & 0,50 & 40,00 & 20,00 & 6,67 & 14,65 & 17,75 & 39,07 \\
\hline
\end{tabular}

For the IVI calculated at 90 DAS in the second year of the winter coverings experiment conduction (2012), it was observed that the species Bidens spp. (Asteraceae) presented higher value for the treatments: uncultivated $(140,23)$, ryegrass $(105,0)$, black oat $(165,45)$ and wheat $(150,21)$ (Table 5). For the wild radish and vetch treatments, the highest IVI were obtained for the species: Sorghum bicolor (144,02), belonging to the Poaceae family, and Galinsoga parviflora (168,33), belonging to the Asteraceae family, respectively (Table 5). It was observed, on a general manner, that the Asteraceae family highlighted from the remaining families within the evaluated treatments.

Relating both years of winter covering plants, it is observed that there was an alteration in the IVI for the treatments, concerning the weed species, where Bidens spp. reached a higher importance in the second year (Table 5); this result might be associated to the purposeful infestation realized during the sowing of the winter coverings in the first year of the experiment. The increase in frequency and dominance of the species Bidens spp. for the second year of the experiment conduction might be possibly related 
Table 5. Species, frequency (F), dominance (D), abundance (A), relative frequency (RF), relative dominance (RD), relative abundance (RA) of weeds, importance value index (IVI), 90 Days After Seeding (DAS) of species used as cover during the winter. UFSM, Campus de Frederico Westphalen, RS, 2012.

\begin{tabular}{ccccccccc}
\hline Treatment & Species & $\mathrm{F}$ & $\mathrm{D}$ & $\mathrm{A}$ & $\mathrm{FR}(\%)$ & $\mathrm{DR}(\%)$ & $\mathrm{AR}(\%)$ & $\mathrm{IVI}$ \\
\hline \multirow{3}{*}{ Fallow } & Bidens spp. & 1,00 & 316 & 79,00 & 20,00 & 69,91 & 50,32 & 140,23 \\
& Apium leptophyllum & 1,00 & 24 & 6,00 & 20,00 & 5,31 & 3,82 & 29,13 \\
& Euphorbia heterophylla & 0,50 & 20 & 10,00 & 10,00 & 4,42 & 6,37 & 20,79 \\
\hline \multirow{3}{*}{ Ryegrass } & Bidens spp. & 0,25 & 8 & 8,00 & 25,00 & 40,00 & 40,00 & 105,00 \\
& Bowlesia incana & 0,25 & 4 & 4,00 & 25,00 & 20,00 & 20,00 & 65,00 \\
& Ipomoea spp. & 0,25 & 4 & 4,00 & 25,00 & 20,00 & 20,00 & 65,00 \\
\hline \multirow{3}{*}{ Turnip } & Bidens spp. & 0,50 & 16 & 8,00 & 20,00 & 11,43 & 13,95 & 45,38 \\
& Sorghum bicolor & 0,75 & 88 & 29,33 & 30,00 & 62,86 & 51,17 & 144,02 \\
& Sonchus oleraceus & 0,50 & 16 & 8,00 & 20,00 & 11,43 & 13,95 & 45,38 \\
\hline \multirow{2}{*}{ Vetch } & Galinsoga parviflora & 0,25 & 12 & 12,00 & 33,33 & 60,00 & 75,00 & 168,33 \\
& Lolium multiflorum & 0,50 & 8 & 4,00 & 66,67 & 40,00 & 25,00 & 131,67 \\
\hline \multirow{3}{*}{ Black oats } & Bidens spp. & 0,75 & 40 & 13,33 & 50,00 & 66,67 & 48,79 & 165,45 \\
& Sonchus oleraceus & 0,50 & 12 & 6,00 & 33,33 & 20,00 & 21,95 & 75,29 \\
& Ipomoea spp & 0,25 & 8 & 8,00 & 16,67 & 13,33 & 29,27 & 59,27 \\
\hline \multirow{2}{*}{ Wheat } & Bidens spp. & 0,75 & 80 & 26,67 & 33,33 & 71,43 & 45,45 & 150,21 \\
& Ipomoea spp & 0,25 & 4 & 4,00 & 11,11 & 3,57 & 6,82 & 21,50 \\
& Bowlesia incana & 0,25 & 8 & 8,00 & 11,11 & 7,14 & 13,64 & 31,89 \\
\hline
\end{tabular}

to the area infestation performed in 2011, which refers to the idea that there was emergence in summer and a large scale seed production due to the observed population in the survey performed in the second year; furthermore, the high sorghum infestation in the treatments with wild radish (Table 5) is related to crop rotation, since that in summer the sorghum was utilized as soil covering in the parcels in which wild radish was used as covering, during winter.

Regarding the soil coverings utilized in the summer period, for the evaluations performed at 28 DAE in both years in which the study was conducted, no significative difference was verified as to the number of recorded weed species (Table 6). No significative difference was also found for the number of families of weed species for the first year; as to the following year, the higher occurrence of weed species was observed in the black velvet bean treatment, with eight occurrent species (Table 6); the fact that this area with black velvet bean was uncultivated during winter might justify the superiority in number of existent species compared to the remaining treatments which had covering plants during winter.

Table 6. The total amount of weed species (plants $\mathrm{m}^{-2}$ ), and the number of families of many species, identified through the phytosociological survey by the 28 days after emergence (DAE) of the summer cover plants. UFSM, Campus de Frederico Westphalen, RS, 2011-2012/2013.

\begin{tabular}{|c|c|c|c|c|}
\hline \multirow[t]{3}{*}{ Treatment } & \multicolumn{4}{|c|}{$28 \mathrm{DAE}$} \\
\hline & \multicolumn{2}{|c|}{ Total species number } & \multicolumn{2}{|c|}{ Familes } \\
\hline & $2011 / 12$ & $2012 / 13$ & $2011 / 12$ & $2012 / 13$ \\
\hline Black velvet bean & $6 a$ & $8 a$ & $5 a$ & $9 a$ \\
\hline Gray velvet bean & $6 a$ & $7 a$ & $3 a$ & $4 \mathrm{~b}$ \\
\hline Sorghum & $7 a$ & $5 a$ & $4 a$ & $3 b$ \\
\hline Dwarf velvet bean & $4 a$ & $6 a$ & $5 a$ & $3 b$ \\
\hline Green velvet bean & $5 a$ & $5 a$ & $4 a$ & $3 b$ \\
\hline Sunflower & $6 a$ & $5 a$ & $4 a$ & $4 \mathrm{~b}$ \\
\hline c.v. (\%) & 26,9 & 23,7 & 30,77 & 21,5 \\
\hline
\end{tabular}

Through the phytosociological analysis performed at 28DAE in 2011/12, a lower frequency of weeds was observed for the treatment with sorghum cover compared to the infesting weed Ipomoea spp., highlighted in all treatments.
As to the IVI for the referred species, it was the lowest observed in the sorghum cover, followed by sunflower (Table 7), with this result possibly associated to a higher production of shoot dry mass, comparing with the remaining studied 
coverings (Table 2). The dwarf velvet bean was the cover species which offered a higher result for the IVI parameter calculated for the Ipomoea spp. (Table 7), corroborating the results observed by Lamengo et al. (2015), in which they verified that the dwarf velvet bean presented higher phytosociological indexes among the studied soil coverings for Raphanus spp. These results might be related to the higher amount of dry mass produced by the covering (Table 2), if compared to the results obtained, for example, by sorghum and sunflower. Furthermore, according to Formentini et al. (2009) the maximum shoot dry mass production that the dwarf velvet bean might reach lies around 4 t ha- ${ }^{-1}$.

Table 7. Species, frequency (F), dominance (D), abundance (A), relative frequency (RF), relative dominance (RD), relative abundance (RA) of weeds, importance value index (IVI), 28 days after the species emergence as summer covering plants. UFSM, Campus de Frederico Westphalen, RS, 2011/2012.

\begin{tabular}{ccccccccc}
\hline Treatment & Specie & $\mathrm{F}$ & $\mathrm{D}$ & $\mathrm{A}$ & $\mathrm{RF}(\%)$ & $\mathrm{RD}(\%)$ & $\mathrm{RA}(\%)$ & $\mathrm{IVI}$ \\
\hline \multirow{3}{*}{ Sunflower } & Ipomoea spp & 0,75 & 40,0 & 13,33 & 25,0 & 47,62 & 29,41 & 102,03 \\
& Bidens spp. & 0,75 & 12,0 & 4,0 & 25,0 & 14,29 & 8,82 & 48,11 \\
& Euphorbia heterophylla & 0,5 & 8,0 & 4,0 & 16,67 & 9,52 & 8,82 & 35,01 \\
\hline \multirow{2}{*}{ Sorghum } & Ipomoea spp. & 0,5 & 16,0 & 7,0 & 25,0 & 40,0 & 30,73 & 95,73 \\
& Bidens spp. & 0,25 & 4,0 & 4,0 & 12,5 & 10,0 & 17,39 & 39,89 \\
& Euphorbia heterophylla & 0,5 & 8,0 & 4,0 & 25,0 & 20,0 & 17,39 & 62,39 \\
\hline \multirow{2}{*}{ Black velvet } & Ipomoea spp. & 1,0 & 60,0 & 15,0 & 36,36 & 46,87 & 29,41 & 112,64 \\
bean & Bidens spp. & 0,75 & 48,0 & 16,0 & 27,27 & 37,5 & 31,37 & 96,14 \\
& Euphorbia heterophylla & 0,25 & 8,0 & 8,0 & 9,09 & 6,25 & 15,69 & 31,03 \\
\hline \multirow{2}{*}{ Gray velvet } & Ipomoea spp & 0,75 & 40,0 & 13,33 & 37,5 & 55,56 & 45,46 & 138,52 \\
bean & Euphorbia heterophylla & 0,25 & 4,0 & 4,0 & 12,5 & 5,56 & 13,64 & 31,69 \\
& Xanthium strumarium & 0,75 & 24,0 & 8,0 & 37,5 & 33,33 & 27,28 & 98,11 \\
\hline \multirow{2}{*}{ Dwarf velvet } & Ipomoea spp. & 1,0 & 112,0 & 28,0 & 36,36 & 73,68 & 43,76 & 153,8 \\
bean & Bidens spp. & 0,25 & 12,0 & 12,0 & 9,09 & 7,89 & 18,75 & 35,73 \\
& Galinsoga parviflora & 0,5 & 8,0 & 4,0 & 18,18 & 5,26 & 6,25 & 29,69 \\
\hline \multirow{2}{*}{ Green velvet } & Ipomoea spp. & 1,0 & 60,0 & 15,0 & 40,0 & 68,18 & 38,46 & 146,64 \\
bean & Bidens spp. & 0,5 & 8,0 & 4,0 & 20,0 & 9,09 & 10,25 & 39,34 \\
& Euphorbia heterophylla & 0,25 & 4,0 & 4,0 & 10,0 & 4,55 & 10,26 & 24,8 \\
\hline
\end{tabular}

According to the calculated parameters, it is observed that for the second year of experiment conduction with the summer coverings, the IVI was superior for the species Bidens spp., followed by the species Ipomoea spp., occurring an inversion, comparing it with the previous year (Table 8). The covering which presented a lower index for this parameter was again sorghum followed by sunflower. As to the sunflower, there are studies which infer that even in the seedling stage it is capable of inhibiting the germination or to compromise root and shoot growth in Bildens pilosa (Silva et al. 2009); studies performed by Macías et. al (2003) indicate yet that the crop might interfere in the development of neighboring plants through allelopathy, although the method of action of these allelopathic compounds is little known.

As to the sorghum, the observed reduction in the phytosociological parameters (Table 8) might also be associated to the synthetization of allelopathic substances, in this example, the sorgoleone (Santos et. al, 2012). The mixture of lipid substances associated to specialized enzymes 2-hidroxi- 5metoxi-3-[(Z,Z)8',11',14'-pentadecatriene]- p-benzoquinone is known as sorgoleone (Dayan, 2006), which is naturally produced in the trichomes of sorghum roots; in contact with the weeds they are capable of inhibiting their development, by actuating in the inhibition of the photosyntheticall via (Santos et.al, 2012).

The usage of summer covering plants is efficient in the management of weed suppression, although it is dependent of the utilized covering species (Lamego et al., 2015). The amount of dry mass produced and deposited over the soil has a great influence over suppression, since that high amounts of dry mass over the soil tend to reduce the establishment of weed species in function of the decrease of thermal amplitude and the formation of a physical barrier (Monquero et al., 2009), 
Table 8. Species, frequency (F), dominance (D), abundance (A), relative frequency (RF), relative dominance (RD), relative abundance (RA) of weeds, importance value index (IVI), 28 days after the specie's emergence as summer cover. UFSM, Campus de Frederico Westphalen, RS, 2012/2013.

\begin{tabular}{ccccccccc}
\hline Treatment & Specie & $\mathrm{F}$ & $\mathrm{D}$ & $\mathrm{A}$ & $\mathrm{RF}(\%)$ & $\mathrm{RD}(\%)$ & $\mathrm{ra}(\%)$ & IVI \\
\hline \multirow{3}{*}{ Sunflower } & Bidens spp. & 1,0 & 112,0 & 28,0 & 26,7 & 57,1 & 49,1 & 132,9 \\
& Ipomoea spp & 1,0 & 36,0 & 9,0 & 26,7 & 18,4 & 15,8 & 60,8 \\
& Solanum americanum & 0,8 & 24,0 & 8,0 & 20,0 & 12,2 & 14,0 & 46,3 \\
\hline \multirow{3}{*}{ Sorghum } & Bidens spp. & 1,0 & 44,0 & 11,0 & 30,8 & 35,5 & 23,1 & 89,3 \\
& Ipomoea spp & 0,5 & 28,0 & 14,0 & 15,4 & 22,6 & 29,4 & 67,3 \\
& Xanthium strumarium & 0,8 & 24,0 & 8,0 & 23,1 & 19,4 & 16,8 & 59,2 \\
\hline \multirow{2}{*}{ Black velvet } & Bidens spp. & 1,0 & 1408,0 & 352,0 & 25,0 & 90,5 & 86,3 & 201,8 \\
bean & Euphorbia heterophylla & 1,0 & 72,0 & 18,0 & 25,0 & 4,6 & 4,4 & 34,0 \\
& Xanthium strumarium & 0,5 & 24,0 & 12,0 & 12,5 & 1,5 & 2,9 & 17,0 \\
\hline \multirow{2}{*}{ Gray velvet } & Bidens spp. & 1,0 & 1724,0 & 431,0 & 22,2 & 91,9 & 89,1 & 203,2 \\
bean & Ipomoea spp & 1,0 & 36,0 & 9,0 & 22,2 & 1,9 & 1,9 & 26,0 \\
& Euphorbia heterophylla & 1,0 & 56,0 & 14,0 & 22,2 & 3,0 & 2,9 & 28,1 \\
\hline \multirow{2}{*}{ Dwarf velvet } & Bidens spp. & 1,0 & 612,0 & 153,0 & 21,1 & 70,8 & 67,2 & 159,1 \\
bean & Ipomoea spp. & 1,0 & 160,0 & 40,0 & 21,1 & 18,5 & 17,6 & 57,1 \\
& Cynodon dactylon & 0,8 & 20,0 & 6,7 & 15,8 & 2,3 & 2,9 & 21,0 \\
\hline \multirow{2}{*}{ Green velvet } & Bidens spp. & 1,0 & 2244,0 & 561,0 & 28,6 & 93,2 & 90,7 & 212,5 \\
bean & Ipomoea spp. & 0,8 & 64,0 & 21,3 & 21,4 & 2,7 & 3,5 & 27,5 \\
& Euphorbia heterophylla & 1,0 & 72,0 & 18,0 & 28,6 & 3,0 & 2,9 & 34,5 \\
\hline
\end{tabular}

In the first year of the winter coverings, Bowlesia incana was a highlighted weed species among coverings, differently from Ipomoea spp., which was the one with higher IVI in the uncultivated treatment. In summer, however, Ipomoea spp. Was the predominant weed, independently of the cultivated vegetal covering. In sequence, in the second year of the winter coverings, the purposeful sowing of Bidens spp. was stablished in the area, being this weed the predominant among coverings. This infestation was repeated in the experimental area in the summer coverings and was better suppressed when of the succession of wild radish in winter to sorghum in summer, comparing with the remaining coverings.

For the second year, in winter, the vetch covering presented a higher IVI for Bidens spp. However, in summer, being the sunflower the succession crop for the vetch, this parameter was inferior to the results obtained for the velvet beans, highlighting the suppression capacity of the sunflower over the weed.

Although the infestation by Bidens spp. in the second evaluation year was elevated, a reduction was observed in the treatments in which sorghum and sunflower were the summer covering plants. The vegetal mass produced by the coverings must be considered (Table 2), which is responsible for the physical effect of weed suppression; this might be completed by a produced allelochemical, although this study has not focused in its determination. The sorghum capacity of synthetizing the sorgoleone substance in its root trichomes is widely known, associating it to the weed control in its cultivation areas (Santos et al., 2012).

According with a work developed by Meschede et al. (2007), evaluations performed in different types of soil covering in the cerrado region involving sorghum, millet and crotalaria demonstrated significative weed suppression, as well as higher soil covering by these species. In a study with corn straw over the soil, a numerically inferior emergence of weeds was verified, comparing with the uncultivated area (Luz et al, 2014). Studies also described that the decomposition of the oat straw in the soybean crop presented positive effects over the incidence of weeds, not affecting the grain yield of the crop (Pereira et al., 2011).

Considering the negative effects of the competition generated by the weeds with the cultivated plants, the utilization of strategies for the management of these weeds in the production environments is utterly necessary. With the current society demand for cleaner and sustainable technologies, the usage of covering plants aiming the support in the weed control becomes an important tool for the integrated 
management of these unwanted species. Studies such as this might provide information for the establishment of efficient alternatives in production systems, avoiding significative reductions in the yield of agricultural crops, aside from offering a possible lower impact to the environment through the reduction of herbicide usage.

\section{Conclusions}

The cultivation of ryegrass, black oat, vetch, wheat and wild radish as winter covering plants contributes for the emergence suppression of weeds when compared to the area left uncultivated, with a higher suppressive effect obtained by ryegrass and wild radish coverings.

Sorghum and sunflower are efficient in the production of vegetal mass, decreasing the intensity of emergent weed species, specially Bidens spp., when compared to the species of black velvet bean, dwarf velvet bean and gray velvet bean.

\section{Acknowledgments}

The authors thank the research funding agencies FAPERGS, CAPES and CNPq for the graduate and postgraduate scholarships of the post-graduation program in Agronomy: Agriculture and Environment - PPGAAA/UFSM. To Prof. Antonio Luis Santi of UFSM, Campus of Frederico Westphalen for the donation of the provided seeds.

\section{References}

Balbinot JR, A. A., Moraes, A., Backes, R.L. 2007. Efeito de coberturas de inverno e sua época de manejo sobre a infestação de plantas daninhas na cultura de milho. Planta Daninha 25: 473-480.

Constantin, J. 2007. Métodos de Manejo. In: Oliveira Jr, R. S., Constantin, J., Inove, M., H. Biologia e Manejo de Plantas Daninhas. Omnipax, Curitiba, Brazil. 348p.

Dayan, F.E. 2006. Factors modulating the levels of the allelochemical sorgoleone in Sorghum bicolor. Planta 224: 339-346.

Formentini, E.A., Lóss, F.R., Bayerl, M.P., Lovati, R.D., Baptisti, E. 2008. Cartilha sobre adubação verde e compostagem. INCAPER, Vitória, Brazil. $27 \mathrm{p}$.

Lamego, F. P., Caratti, F. C., Reinehr, M., Gallon, M., Santi, A. L., Basso, C. J. 2015. Potencial de supressão de plantas daninhas por plantas de cobertura de verão. Comunicata Scientiae 6: 97-105.

Gomes JR., F. G., Christoffoleti, P. J. 2008. Biologia e manejo de plantas daninhas em áreas de plantio direto. Planta Daninha 26: 789-798.

Kadioglu, I., Yanar, Y., Asav, U. 2005. Allelopathic effectsof weeds extracts againstseed germination of some plants. Journal of Environmental Biology 26:169-173.

Lorenzi, H. 2006. Manual de identificação e controle de plantas daninhas: plantio direto e convencional. Instituto Plantarum, Nova Odessa, BR. 339 p.

LuZ, F. N., Yamashita, O. M., Ferraresi , D. A., Carvalho, M. A. C., Campos, O. R., Koga, P. S., Massaroto, J. A. 2014. Interferência de luz, temperatura, profundidade de semeadura e palhada na germinação e emergência de Murdannia nudiflora. Comunicata Scientiae 5: 25-33.

Macías, F. A. et al. 2003. Allelopathy as a new strategy for sustainable ecosystems development. Biological Sciences in Space, 17:18-23,

Meschede, D.K., Ferreira, A.B., Ribeiro JR, C.C. 2007. Avaliação de diferentes coberturas na supressão de plantas daninhas no Cerrado. Planta Daninha 25:465-471.

Monquero, P.A., Amaral, L.R., Inácio, E.M., Brunhara, J.P., Binha, D.P., Silva, P.V., Silva, A.C. 2009. Efeito de adubos verdes na supressão de espécies de plantas daninhas. Planta Daninha 27:85-95.

Moraes, P.V.D., Agostinetto, D., Vignolo, G.K., Santos, L.S., Panozzo, L.E. 2009. Manejo de plantas de cobertura no controle de plantas espontâneas na cultura do milho. Planta Daninha 27:289-296.

Mueller, D., Ellenberg, H.A. 1974. Aims and methods of vegetation ecology. John Wiley. Nova lorque, EUA. 547 p.

Oliveira, A.R., Freitas, S.P. 2008. Levantamento fitossociológico de plantas daninhas em áreas de produção de cana-de-açúcar. Planta Daninha 26: 33-46.

Pereira, R.A., Alves, P.L.C.A., Corrêa, M.P., Dias, T.C.S. 2011. Influência da cobertura de aveiapreta e milheto sobre comunidade de plantas daninhas e produção de soja. Revista de Ciências Agrárias 6: 1-11.

Pires, N. M., Oliveira, V.R. 2007. Alelopatia. In: Oliveira Jr, R. S., Constantin, J., Inove, M., H. Biologia e Manejo de Plantas Daninhas. Omnipax, 
Curitiba, BR. 348p.

Rizzardi, M.A., Silva, L.F. 2006. Influência das coberturas vegetais antecessoras de aveiapreta e nabo-forrageiro na época de controle de plantas daninhas em milho. Planta Daninha 24: 669-675.

Santos, I.L.V.L., Silva, C.R.C., Maia,, M.M.D. 2012. Sorgoleone: Benzoquinona lipídica de sorgo com efeitos alelopáticos na agricultura como herbicida. Arquivos do Instituto Biologico 79:135144.

Silva, H.L., Trezzi. M.M., Marchese, J.A., Buzzello, G., Miotto Jr. E., Patel, F., Debastiani, F., Fiorese, J. 2009. Determinação de espécie indicadora e comparação de genótipos de girassol quanto ao potencial alelopático. Planta Daninha 27: 655-663.

Souza, L.S., Velini, E.D., Martins, D., Rosolem, C.A. 2006. Efeito alelopático de capim-braquiária (Brachiaria decumbens) sobre o crescimento inicial de sete espécies de plantas cultivadas. Planta Daninha 24: 657-668. 